\title{
Т.И. Белюкова
}

\section{НЕКОТОРЫЕ ПРОБЛЕМЫ, ВОЗНИКАЮЩИЕ В ПРОЦЕССЕ ИСПОЛНЕНИЯ ОТСРОЧКИ ОТБЫВАНИЯ НАКАЗАНИЯ ПО ст. 82 УК РФ, И ПУТИ ИХ РЕШЕНИЯ}

\begin{abstract}
Освешаются проблемы, с которыми сталкиваются сотрудники уголовноисполнительных инспекций в процессе исполнения отсрочки отбывания наказания в отношении беременных женщиин и лиц, имеющих малолетних детей. $\mathrm{K}$ таковым относятся: излишняя свобода и отсутствие чувства ответственности у осужденных за совершенное преступление в силу наличия всего одной обязанности, недостаточность средств и методов воздействия на осужденных. Анализируя имеюшиеся трудности, автор предлагает пути их решения.

Ключевые слова: отсрочка отбывания наказания, беременные женщины, малолетние дети, уголовно-исполнительные инспекиии.
\end{abstract}

Институт отсрочки отбывания наказания достаточно молодой, появился он в уголовном законодательстве с принятием Закона Российской Федерации № 2988-1 от 12 июня 1992 г. «О внесении изменений и дополнений в ИТК РСФСР, УК РСФСР, УПК РСФСР» [1], который вводил ст. $46^{2}$, регламентирующую предоставление отсрочки беременным женщинам и женщинам, имеющим малолетних детей в возрасте до трех лет. На протяжении долгих лет институт претерпевал изменения, направленные на его совершенствование, однако и в настоящее время все еще возникают определенные трудности, связанные с реализацией указанного института на практике.

Представленные ниже данные основываются на проведенном автором исследовании - анкетировании 250 сотрудников уголовно-исполнительных инспекций, на учете которых состоят осужденные к отсрочке отбывания наказания в связи с беременностью или наличием малолетних детей, а также анкетировании 850 осужденных-отсрочников в 15 регионах Российской Федерации.

В ходе исследования были выявлены следующие проблемы, возникающие при исполнении отсрочки отбывания наказания.

Часть сотрудников уголовно-исполнительных инспекций (25 \%) отмечают, что отсрочка отбывания наказания - неэффективный вид освобождения в плане исправления осужденных. Связано данное мнение с рядом причин:

- наличием всего одной обязанности у осужденных (воспитание ребенка и уход за ним);

- излишней свободой осужденных и отсутствием чувства ответственности за совершенное преступление;

- недостаточностью методов и средств воздействия на осужденных.

Наличие у осужденных всего одной обязанности (по воспитанию и уходу за ребенком), по мнению сотрудников уголовно-исполнительных инспекций, 
которое поддерживаем и мы, недостаточно для эффективного контроля за осужденными. Для законопослушных граждан воспитание детей, обеспечение им надлежащих условий развития является проявлением родительской любви по отношению к своим детям, а поскольку в некоторых случаях осужденные родители используют детей для продолжения противоправного, аморального образа жизни, предоставление суду права возлагать на осужденных дополнительные обязанности видится нам необходимым.

Примерные обязанности, на наш взгляд, должны выглядеть следующим образом:

1) возместить причиненный совершенным преступлением вред. Осужденный должен отчитываться перед уголовно-исполнительной инспекцией о погашении долга. С целью проверки данных о погашении суммы ущерба необходима организация взаимодействия со службой судебных приставовисполнителей, которые по запросам сотрудников УИИ должны ежеквартально представлять сведения о сумме возмещенного ущерба;

2) являться в уголовно-исполнительную инспекцию как на первоначальную регистрацию после вынесения судом постановления об отсрочке, так и на профилактические беседы (от 1 до 4 раз в месяц).

Сотрудники инспекций отмечают, что нет рычагов воздействия на осужденных в случае их неявки в УИИ для проведения беседы. На наш взгляд, если осужденный не является в установленный срок в УИИ, ему должно объявляться предупреждение.

Периодические явки осужденных в уголовно-исполнительную инспекцию должны сопровождаться отчетом осужденного о своем поведении и исполнении обязанностей по воспитанию ребенка и уходу за ним (о проведенных с ребенком развивающих, развлекательных мероприятий, посещении медицинских специалистов с предоставлением подтверждающих материалов). В случае необходимости и при наличии оснований отчет о воспитании ребенка должен заслушиваться работниками комиссий по делам несовершеннолетних и защите их прав.

В отношении условно осужденного сотрудник УИИ в случае неявки на регистрацию без уважительных причин может вынести постановление о приводе (при необходимости направляется копия в орган внутренних дел с ходатайством об оказании помощи в доставлении осужденного). В отношении осужденных к отсрочке отбывания наказания данной меры не предусмотрено, по всей видимости, в силу этических причин. На наш взгляд, применение данной меры в отношении осужденных к отсрочке было бы приемлемым в случае систематической неявки осужденного на регистрацию (более двух раз) при соответствующем поведении (проявление грубости по отношению к сотрудникам, отказ в проверке по месту жительства и т.д.) за тем дополнением, что в процессе привода должны участвовать работники органов опеки и попечительства, на которые должна возлагаться обязанность по контролю за ребенком (детьми) в отсутствие матери;

3) проходить обследование у врача-нарколога перед предоставлением отсрочки, при наличии соответствующего заключения пройти курс лечения от алкоголизма, наркомании. В случае отказа - вынесение предупреждения ли- 
цу; повторный отказ должен предшествовать принудительному доставлению лица в медицинское учреждение.

Обусловлено установление данной обязанности следующим. Сотрудники уголовно-исполнительных инспекций отмечают, что многие осужденные социально запущенные лица, они не могут или не хотят менять свой образ жизни, устраиваться на работу, употребляют спиртные напитки, наркотические вещества. В практике сотрудников УИИ были случаи, когда осужденная мать оставила пятерых детей без присмотра, употребляла спиртные напитки в течение трех дней, дети были предоставлены сами себе; дети были изъяты сотрудниками Отдела по делам несовершеннолетних и защите их прав и помещены в Реабилитационный центр временного содержания помощи семье и детям, сама же осужденная проживала в центре, и дети не были ей возвращены до момента кодирования матери от алкогольной зависимости. Однако не во всех регионах развито конструктивное сотрудничество органов системы профилактики преступлений с уголовно-исполнительной инспекцией по вопросам исправления осужденных и оказания им различных видов помощи, поэтому установление обязанности прохождения осужденными обследования у врача-нарколога будет выступать дополнительной гарантией защиты прав детей, находящихся на воспитании осужденных;

4) не менять место жительства без уведомления УИИ;

5) в ночное время (с 22:00 до 6:00) находиться по месту проживания, в противном случае - вынесение предупреждения;

6) трудоустроиться, в том числе и по выходу из отпуска по уходу за ребенком (в основном семьи малоимущие, родители не работают, поэтому трудоустройство осужденных в период отсрочки представляется необходимым и влияет как на исправление осужденных, так и предупреждение совершения повторных преступлений. О необходимости привлечения осужденных к труду свидетельствуют многие ученые, среди которых, например, В.А. Уткин, отмечающий, что суждение о недопустимости обязательного труда осужденных является несостоятельным [2. С. 83]);

7) в случае необходимости, отсутствия навыков и опыта работы - получить образование, пройти обучение (переподготовку) новой профессии, в том числе и во время декретного отпуска (возможно, и дистанционно).

Наличие трех и более предупреждений (в зависимости от характера допущенных нарушений), на наш взгляд, должно являться основой для подачи в суд представления об отмене отсрочки отбывания наказания и направлении лица для отбывания наказания, назначенного приговором суда.

Мы считаем, что предоставление суду права возлагать на осужденных дополнительные обязанности должно повысить эффективность отсрочки. Необходимо добиться, чтобы осужденные чувствовали ответственность за совершенное преступление, ведь, как отмечают сотрудники инспекций, часть осужденных считают, что их освободили от наказания, «они никому ничего не должны». Следствием такого восприятия выступает соответствующее поведение осужденных: грубость по отношению к сотрудникам, воспрепятствование входу в дом для осуществления проверки. Не зря некоторые авторы отмечают, что «оставить без последствий проступок - это значит поощрить нарушителя» [3. С. 19]. Именно поэтому установление дополнительных обя- 
занностей для осужденных к отсрочке представляется необходимым и целесообразным.

По поводу недостаточности имеющихся средств и методов воздействия на осужденных у контролирующего органа хотелось бы пояснить следующее.

Согласно Инструкции по организации исполнения наказаний и мер уголовно-правового характера без изоляции от общества [4] сотрудник УИИ проводит профилактические беседы с осужденными при их ежемесячной явке в инспекцию, а также не реже одного раза в месяц посещает осужденных с целью проверки материально-бытовых условий проживания. При реализации данных обязанностей сотрудник инспекции сталкивается с рядом проблем. Во-первых, неявка на профилактические беседы (решение данной проблемы было предложено выше). Во-вторых, нежелание отдельных категорий осужденных впускать сотрудника в дом для проверки, проявление грубости по отношению к нему. Законодательство не конкретизирует действия контролирующего органа в данном случае. Мы считаем, что необходимо предоставить сотруднику право вынесения предупреждения осужденному, составление по данному вопросу справки, с которой осужденный должен быть ознакомлен. В случае повторной неявки осужденного в инспекцию, грубого обращения с сотрудником - составление представления с последующим направлением его в суд для решения вопроса об отмене отсрочки (либо, в случае законодательного установления дополнительных обязанностей указанным категориям осужденных, их назначение). В-третьих, сотрудник не обладает сведениями, что считать нормой при обследовании жилищно-бытовых условий. В данном случае, как нам видится, необходимо внести дополнение в Инструкцию по организации исполнения наказаний и мер уголовно-правового характера без изоляции от общества, разъяснив, на что должен обращать внимание сотрудник при посещении осужденного. А именно:

- общее состояние квартиры (пол, стены, отопление, проветривание и т.п.);

- наличие места для сна ребенка, приготовления уроков;

- наличие продуктов;

- наличие игрушек (пусть самых простых), школьных принадлежностей, средств личной гигиены (зубная паста, мыло);

- санузел (чистота);

- наличие одежды по сезону;

- наличие домашних животных, чистота их содержания;

- свободный вход и выход из квартиры;

- состояние, внешний вид осужденных родителей и совместно проживающих родственников;

- обеспечение безопасности: отсутствие доступа к опасным предметам в быту, медикаментам, электроприборам;

- факты пренебрежительного, грубого обращения с ребенком, физического или психического насилия над ним.

Устранение обозначенных проблем, установление в законодательстве дополнительных обязанностей осужденным, предоставление сотрудникам уголовно-исполнительных инспекций обращаться в суд с ходатайством об установлении подучетным лицам дополнительных обязанностей на мотивирован- 
ной основе позволит расширить имеющиеся средства и методы воздействия на осужденных, повысив тем самым эффективность деятельности УИИ в исправлении осужденных и предупреждении совершения ими новых преступлений.

Нами обозначены лишь некоторые из проблем, возникающих при исполнении отсрочки отбывания наказания в отношении осужденных, которым отсрочено отбывание наказания в связи с беременностью или наличием малолетних детей. Пути их решения будут зависеть от пересмотра и дополнения уголовного, уголовно-исполнительного законодательства страны.

\section{Литература}

1. Российская газ. 1992. № 164. 21 июля.

2. Уткин B.A. Проблемы правового регулирования труда осужденных в исправительных учреждениях Российской Федерации // Уголовная юстиция. 2015. № 2 (6). С. 81-88.

3. Васильев А.Н. Предупреждение преступлений. М.: Гос. изд-во юрид. лит-ры, 1963.30 с.

4. Об утверждении Инструкции по организации исполнения наказаний и мер уголовноправового характера без изоляции от общества: приказ Минюста России от 20 мая 2009 г. № 142 // СПС «КонсультантПлюс».

Belyukova Tatiana I. Academy of the Federal penitentiary service of Russia (Ryazan, Russian Federation)

SOME PROBLEMS ARISING IN THE COURSE OF EXECUTION OF A DEFERRED SENTENCE UNDER ARTICLE 82 OF THE CRIMINAL CODE OF THE RUSSIAN FEDERATION AND THE WAYS FOR THEIR SOLUTION

Keywords: deferred sentence, pregnant women, children, probation inspectorate.

Despite the changes in criminal legislation regarding improvement of the precepts of law providing the deterred sentence for pregnant women and persons having children, today there are certain difficulties in practice of execution of this type of release from punishment.

The arising problems are connected with the gaps in criminal and penal legislation; departmental regulations regulating the activities of probation inspectorates supervising the above categories of convicts. On the basis of the carried-out questioning of employees of probation inspectorates (250 people) and those convicted to a deferred sentence ( 850 people) in 15 regions of the country, the author revealed the following problems. Inefficiency of a deferred sentence can be explained by the fact that convicts have only one duty (upbringing of a child and care of it); excessive freedom of convicts and lack of sense of responsibility for the committed crimes; insufficiency of methods and instruments of control over convicts.

Proceeding from the above problems, the author offers some possible solutions. Firstly, to authorize the courts to impose additional duties on convicts taking into account the characteristic of their personality and the analysis of all facts of the case.

The suggested duties are the following: to compensate the harm done by the committed crime; to come to a probation inspectorate for initial registration after the court order about a deferred sentence and for a preventive conversation (from 1 to 4 times a month) with the report on child's upbringing; to be carefully examined by a narcologist before serving a deferred sentence and undergo a course of treatment in case of drug or alcohol addiction; not to change the residence without informing a probation inspectorate; at night (from 10p.m. till 6 a.m.) to be in the place of residence; to find a job, including after a parental leave; in case of need, lack of skills and experience - to get an education, to be trained (retrained) including the period during a maternity leave (it is possible to do it remotely).

The specified duties can be changed or added by the court.

According to the author, establishment of additional duties will discipline the convict and increase his responsibility for the committed crime. The author emphasizes that increase in efficiency of deferred sentences is possible by introduction of amendments and additions to current legislation of the country. 


\section{References}

1. Rossiyskaya gazeta. (1992) 21 st July.

2. Utkin, V.A. (2015) [On legal regulation of the labour of convicts in correctional institutions of the Russian Federation]. Ugolovnaya yustitsiya - Russian Journal of Criminal Law. 2(6). pp. 81-88. (In Russian). DOI: 10.17223/23088451/6/16

3. Vasiliev, A.N. (1963) Preduprezhdenie prestupleniy [Prevention of crimes]. Moscow: Gos. izd-vo yurid. lit-ry.

4. Ministry of Justice of the Russian Federation. (2009) On the approval of the Instruction on the organization of execution of punishments and penal measures without isolation from society: Order No. 142 of the Ministry of Justice of Russia: dated May 20, 2009. [Online] Available from: http://www.consultant.ru/document/Cons_doc_LAW_89167/. (In Russian). 